\title{
Conference Paper \\ Oxidation State of a Polyurethane Membrane after Plasma Etching
}

\author{
Matthew D. Moles, ${ }^{1}$ Colin A. Scotchford, ${ }^{2}$ and Alastair Campbell Ritchie ${ }^{2}$ \\ ${ }^{1}$ Division of Electrical Systems and Optics, Faculty of Engineering, University of Nottingham, University Park, \\ Nottingham NG7 2RD, UK \\ ${ }^{2}$ Division of Materials, Mechanics and Structures, Faculty of Engineering, University of Nottingham, University Park, \\ Nottingham NG7 2RD, UK
}

Correspondence should be addressed to Matthew D. Moles; matthew.moles@nottingham.ac.uk

Received 22 November 2013; Accepted 24 February 2014; Published 8 April 2014

Academic Editors: A. Baykal and J. Gough

This Conference Paper is based on a presentation given by Matthew D. Moles at "UK Society for Biomaterials Annual Conference 2013” held from 24 June 2013 to 25 June 2013 in Birmingham, United Kingdom.

Copyright (C) 2014 Matthew D. Moles et al. This is an open access article distributed under the Creative Commons Attribution License, which permits unrestricted use, distribution, and reproduction in any medium, provided the original work is properly cited.

\begin{abstract}
Low moduli cell culture substrates can be used to apply dynamic mechanical strain to cells, by surface deformation. Understanding the surface interaction with cells is critical to improving cell adhesion and normal growth. A medical grade polyurethane (PU), Chronoflex AL 80A, was modified by oxygen plasma etching and characterised by X-ray photoelectron spectroscopy. Etching resulted in increased cross-linking at the isocyanate bond and formation of new oxygen moieties. The model, derived from patent data and XPS data of the unetched PU, indicated that the additional oxygen was likely to be hydroxyl and carbonyl groups. Etched membranes enhanced protein adhesion, resulting in full surface coverage compared to unetched PU. The etched PU supported cell adhesion and spreading, while the unetched PU was not conducive to monolayer formation.
\end{abstract}

\section{Introduction}

The human body comprises tissues with a range of elastic moduli. Improving the response of in vitro cell- and tissuebased investigations can be achieved by culturing cells upon a substrate with a modulus closer to that of living tissue, as opposed to tissue culture polystyrene that has a modulus an order of magnitude greater than smooth muscle, for example, [1]. In addition, dynamic modulation of the substrate can provide mechanical signals that drive differentiation or proliferation.

Previously, a stable biocompatible polyurethane (PU), Chronoflex AL 80A (AdvanSource Biomaterials, Wilmington, MA), was tested as a low modulus candidate substrate for a bioreactor capable of subjecting cells to a dynamic mechanical environment [2]. PU was selected as it is more resilient [3] and has a better cell response than similar polymers [4]. It was shown that plasma etching is a key factor to the success of cell adhesion and normal cell growth: the wettability was found to be dependent on etching power and duration, while roughness was more affected by the duration [2]. Therefore the state of oxidation of the PU membrane has been examined, in order to understand the effects of plasma etching on protein and cell adhesion.

\section{Method}

2.1. Membrane Manufacture and Modification. PU membranes were produced as described previously [2]. In brief, polyurethane membranes of thickness $200 \pm 10 \mu \mathrm{m}$ (mean \pm standard deviation (SD)) were formed by solvent casting with tetrahydrofuran $(10 \% \mathrm{w} / \mathrm{w})$ and drying in a vacuum oven at $50^{\circ} \mathrm{C}$. Surface modification was carried out by etching using an inductively coupled RF-source $(13.56 \mathrm{MHz})$ plasma barrel etcher (Biorad PT7100). The sample chamber was evacuated to $8 \mathrm{~Pa}$, purged with oxygen (grade 2 nitrogen free, $\mathrm{BOC}$, 
Surrey, UK), and the pressure was maintained at $20 \mathrm{~Pa}$ for $5 \mathrm{~min}$. Samples were then exposed to plasma for $40 \mathrm{~s}$ or $80 \mathrm{~s}$ at powers of $20-180 \mathrm{~W}$.

2.2. X-Ray Photoelectron Spectroscopy. X-ray photoelectron spectroscopy (XPS) spectra of PU membrane samples were recorded using an Axis Ultra (Kratos Analytical, Kyoto, Japan) with monochromated $\mathrm{Al} K_{\alpha}(1486.6 \mathrm{eV})$ radiation source with a pass energy of $80 \mathrm{eV}$ for survey spectra and $20 \mathrm{eV}$ for high resolution spectra; the step size was $0.1 \mathrm{eV}$. The takeoff and acceptance angles were $90^{\circ}$ and $30^{\circ}$, respectively. Two PU membrane samples $(\varnothing 11 \mathrm{~mm})$ were taken from separate batches; three areas $(700 \times 300 \mu \mathrm{m})$ per sample were analysed. By modelling peak envelopes on the spectral data, the relative abundance of each chemical environment may be quantified. Data was interpreted using CasaXPS v2.3.1.6 with the Kratos relative sensitivity factor library. Charge correction was carried out by shifting data relative to the C 1 s peak $(285.0 \mathrm{eV})$. Peak and component (30\% GaussianLorentz distribution) fitting was carried out with a Tougaard background; data smoothing was not applied. Full width half magnitude (FWHM) was constrained to $0.8-1.3 \mathrm{eV}$ for $\mathrm{C} 1 \mathrm{~s}$, $\mathrm{N} 1 \mathrm{~s}$ and $\mathrm{Si} 2 \mathrm{p}$, and $1.5-1.8 \mathrm{eV}$ for $\mathrm{O}$ 1s; peaks with a higher binding energy have greater interference and so have a larger FWHM [5].

2.3. Protein Adsorption. Unetched and etched ( $20 \mathrm{~W} 40 \mathrm{~s}$ ) membranes $(\varnothing 11 \mathrm{~mm})$ were incubated $\left(37^{\circ} \mathrm{C}, 5 \% \mathrm{CO}_{2}\right)$ in 48-well TCPS multiplates for periods of 2 and 5 days with Dulbecco's Modified Eagle Medium (DMEM) with 10\% foetal bovine serum (Fisher Scientific, UK). A control sample was incubated with deionised water. Samples were dried in a nitrogen gas stream after incubation, prior to loading in the XPS analyser.

2.4. Cell Culture. Osteosarcoma MG-63 cells (European Collection of Cell Cultures) were cultured in a humidified $37^{\circ} \mathrm{C}, 5 \% \mathrm{CO}_{2}$ incubator, with culture medium composed of DMEM supplemented with 10\% FBS (Fisher Scientific, UK), 1\% 200 mM L-glutamine, 5\% antibiotics-antimycotics, 5\% $1 \mathrm{M}$ HEPES, 1\% MEM nonessential amino acids, and $0.15 \mathrm{mg} \cdot \mathrm{mL}^{-1} \mathrm{~L}$-ascorbic acid. Passage 25 cells were harvested with $0.25 \%$ trypsin-EDTA and seeded at 20,000 cells $\cdot \mathrm{cm}^{-3}$. Medium and reagents were purchased from Fisher Scientific, UK.

\section{Results}

\subsection{XPS}

3.1.1. Survey Data. Spectral peaks that correspond to carbon (C 1s), oxygen (O 1s), nitrogen (N 1s), and silicon (Si 2p) were present in the survey spectra of all samples. The surface atomic composition, excluding hydrogen (as it is not detected by XPS), was calculated from the relative peak areas of the XPS spectra, and the values are listed in Table 1. The error for some species (e.g., maximum SD of O 1 s was \pm 2.4 ) was increased by a slight batch variation that may arise due to operator error in plasma power or duration control; however, within these batches the error margin is relatively small (e.g., for $\mathrm{O} 1 \mathrm{~s}$, the maximum and minimum SD for the 2 tested batches were $\pm 0.72 / \pm 0.20$ at. $\%$ and $\pm 0.72 / \pm 0.05$ at.\%, resp.). The high variation of the oxygen of the unetched control membrane $( \pm 2.2$ at.\%) demonstrates that localised variance exists after manufacture, prior to further surface treatment.

3.1.2. Silicon. Silicon was not part of the material specification; therefore it is suggested that the source of contamination was silicone oils used in the moulding of the PU pellets and/or packaging extrusion. The high resolution silicon peak of the unetched PU is shown in Figure 1. In all the unetched samples the silicon peak was present at approximately $102.2 \mathrm{eV} \pm$ $0.1 \mathrm{eV}$, which indicates that the silicon was not elemental (99$100 \mathrm{eV}$ [6]) nor was it silicon dioxide, which is known to undergo a chemical shift to approximately $103-104 \mathrm{eV}[6,7]$. The chemical shift suggests that it was a siloxane bond $[6,8]$, which is indicative of a silicone based organic molecule.

In the case of the etched ( 20 and $50 \mathrm{~W}$ ) samples, the Si $2 \mathrm{p}$ peak undergoes chemical shift to approximately $102.9 \mathrm{eV}$, with $1 / 2$ and $3 / 2$ spin states at $102.8 \mathrm{eV}$ and $103.5 \mathrm{eV}$, respectively. This indicates that oxygen has been added, to form $\mathrm{SiO}_{x}$, where $1.8<x<2$. According to the literature [8-12], as the peak maximum was at $102.8 \mathrm{eV}$ the oxidation state is most likely Si III. In addition, the +3 oxidation state is likely to be as a result of coordination with 3 oxygen atoms and 1 carbon atom $\left(\left(\mathrm{CH}_{3}\right) \mathrm{SiO}_{3 / 2}\right)[8,12]$. After etching at 100 or $180 \mathrm{~W}$, the Si 2 p peak was shifted to $103.2-103.5 \mathrm{eV}$, which is characteristic of $\mathrm{SiO}_{2}$ [9-12]. As $\mathrm{Si}$ contributes a significant quantity of oxygen (ca. 10\%), it was included in the model.

3.1.3. Model and High Resolution XPS Data. A possible molecular structure for Chronoflex, shown in Figure 2, was deduced using data published in the manufacturers patent [13]. It was known that the composition was aliphatic; therefore the networking components were most likely $4,4^{\prime}$-dicyclohexylmethane diisocyanate (HMDI) with 1,4-butanediol (1,4-BDO), which are shown linked in Figure 2(b). Given the composition of aliphatic polycarbonates available at the time of the PU invention and based on the patent data, the soft matrix was most likely hexanediol-carbonate glycol (Figure $2(a))$. In addition, the ratio of carbonate to diisocyanate to extender was likely to be $2: 2: 1$ [13]. From this information a table of chemical groups (Table 2), along with the number of chemical environments for $\mathrm{C}, \mathrm{N}$, and $\mathrm{O}$, has been compiled.

In the following analysis, 3 sample categories are presented: unetched PU; PU etched at $20 \mathrm{~W} 40$ s, representative of high surface oxidation, and which was the surface treatment applied to cell culture samples; and PU etched at $20 \mathrm{~W}$ $80 \mathrm{~s}$, representative of low surface oxidation. The component binding energy and area was constrained as shown in Table 2. Using the peak fitting tool it was possible to fit 8 theoretical components to the $\mathrm{C} 1 \mathrm{~s}$ unetched experimental data (Figure 3(a)), based on the known structural moieties of Chronoflex. The model envelope was a close approximation of the XPS data. The C $1 \mathrm{~s}$ model was then imposed upon XPS data from etched samples; area constraints were removed to allow for changes in the composition, but component binding energy constraints remained unchanged. The model did not produce 
TABLE 1: Atomic composition for unetched and etched PU membrane surface as determined by XPS. Data shows mean for 3 scans per sample, $n=2$.

\begin{tabular}{|c|c|c|c|c|c|}
\hline \multirow{2}{*}{ Etching power $(\mathrm{W})$} & \multirow{2}{*}{ Etching duration (s) } & \multicolumn{4}{|c|}{ Atomic concentration percentage (at. $\%) \pm S D$} \\
\hline & & $\mathrm{C}$ & $\mathrm{O}$ & $\mathrm{N}$ & $\mathrm{Si}$ \\
\hline \multirow{3}{*}{20} & & $84.4 \pm 2.18$ & $10.7 \pm 2.2$ & $3.7 \pm 0.18$ & $1.2 \pm 0.14$ \\
\hline & 40 & $76.0 \pm 2.07$ & $19.5 \pm 2.0$ & $3.8 \pm 0.26$ & $0.6 \pm 0.26$ \\
\hline & 80 & $77.9 \pm 0.68$ & $17.3 \pm 0.5$ & $3.9 \pm 0.40$ & $0.9 \pm 0.32$ \\
\hline \multirow{2}{*}{50} & 40 & $77.7 \pm 0.69$ & $17.2 \pm 0.5$ & $4.1 \pm 0.34$ & $1.0 \pm 0.16$ \\
\hline & 80 & $76.6 \pm 0.71$ & $18.4 \pm 0.9$ & $3.9 \pm 0.37$ & $1.1 \pm 0.17$ \\
\hline \multirow{2}{*}{100} & 40 & $77.7 \pm 0.39$ & $17.2 \pm 0.2$ & $3.9 \pm 0.33$ & $1.3 \pm 0.23$ \\
\hline & 80 & $77.1 \pm 2.24$ & $18.4 \pm 2.2$ & $3.7 \pm 0.12$ & $0.9 \pm 0.09$ \\
\hline \multirow{2}{*}{180} & 40 & $75.2 \pm 2.33$ & $20.1 \pm 2.1$ & $3.5 \pm 0.14$ & $1.2 \pm 0.16$ \\
\hline & 80 & $73.6 \pm 2.37$ & $21.8 \pm 2.4$ & $3.4 \pm 0.09$ & $1.1 \pm 0.19$ \\
\hline
\end{tabular}

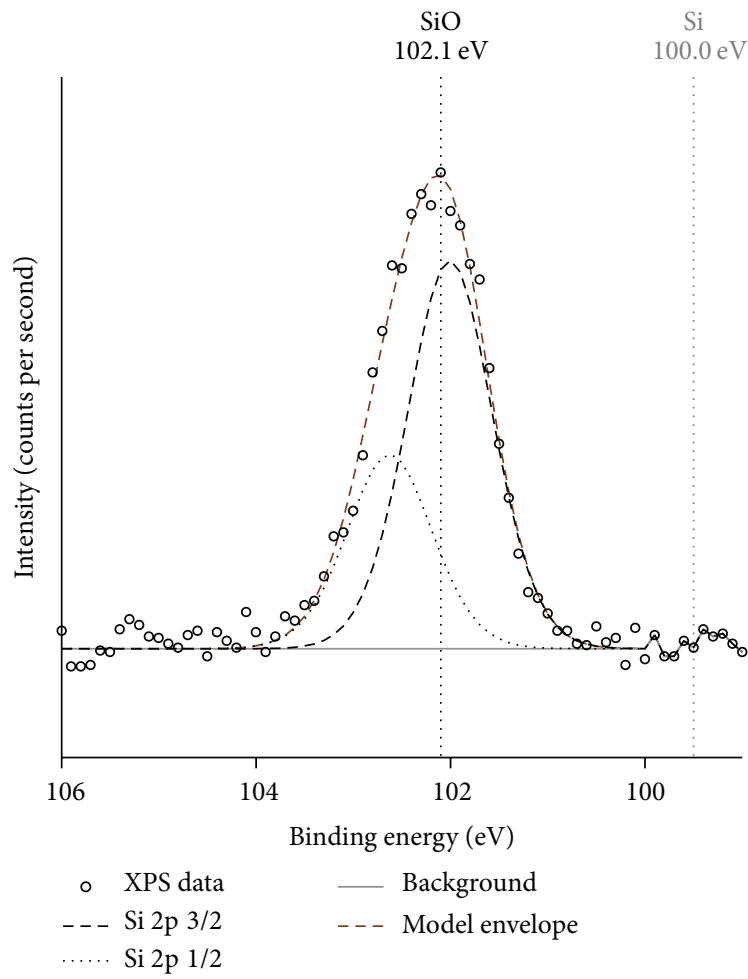

(a)

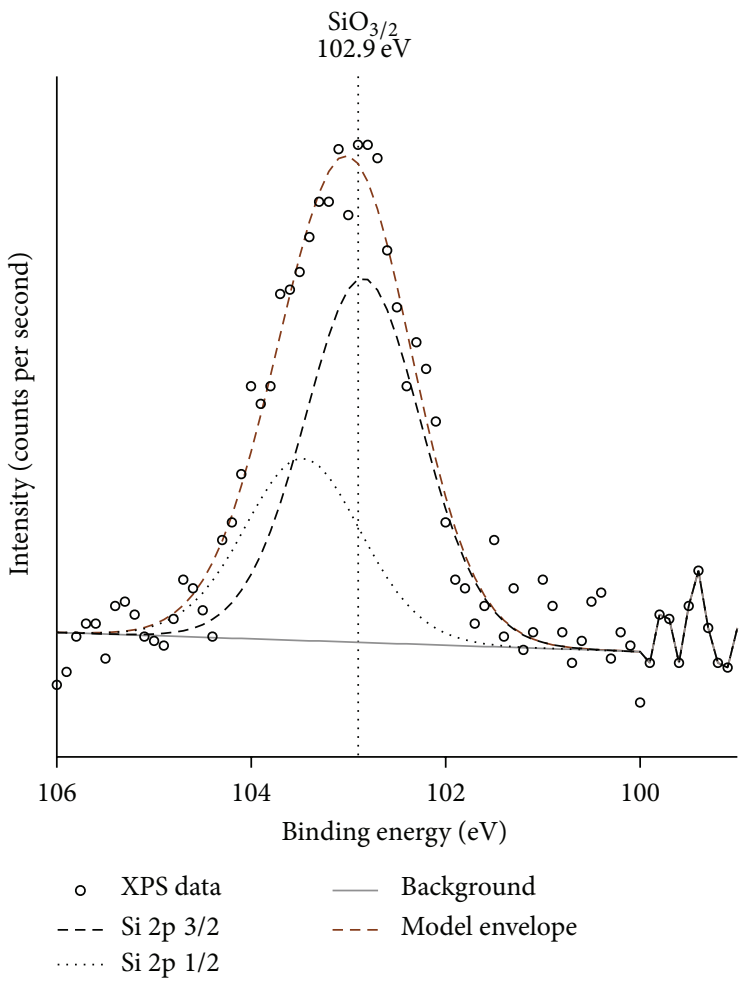

(b)

FIGURE 1: High resolution XPS spectra of the silicon region. (a) Unetched PU membrane; (b) PU membrane etched at $20 \mathrm{~W} 40 \mathrm{~s}$.

a complete fit when applied to the etched sample, indicating significant changes to the chemical structure. A hydroxyl component, assigned to $286.4-286.7 \mathrm{eV}$ [6], did not complete the model. However, a hydroxyl adjacent to a carbonyl (289.2$289.3 \mathrm{eV}$ [6]) would account for the pronounced $289.3 \mathrm{eV}$ shoulder (Figures 3(b) and 3(c)).

The unetched $\mathrm{O} 1 \mathrm{~s}$ peak was fitted with a four-component model (Table 2), along with components for siloxane and an additional carboxyl peak (532.1 eV) (Figure 4(a)). The model for etched samples (Figures 4(b) and 4(c)) required further modification: there was a high possibility of hydroxylation occurring during oxidative plasma etching, and hydroxyls are known to form on oxide coatings [16]. Addition of a hydroxyl component $(533.1 \mathrm{eV}$; constraint was $532.7-533.1 \mathrm{eV}$ [6]; corresponding peak in C $1 \mathrm{~s}: 289.2-289.3 \mathrm{eV} \mathrm{[6])} \mathrm{to} \mathrm{the} \mathrm{O}$ $1 \mathrm{~s}$ peak resulted in a good fit of the model to the XPS data. The hydroxyl binding energy upper constraint was extended from $533.1 \mathrm{eV}$ to $533.5 \mathrm{eV}$, on the basis that it may form close to an $\mathrm{O}$ or $\mathrm{N}$ in the PU structure, which would increase the binding energy. Siloxane was constrained to $532.0 \mathrm{eV} \pm 0.1 \mathrm{eV}[6]$, while for $\mathrm{SiO}_{x}$ the component constraint was $531.0-534.0 \mathrm{eV}$ [8-10]. Silicon oxides, $\mathrm{SiO}_{x}$, have binding energies of $532.2 \mathrm{eV}$ for $x=1.8$ [10], $532.6 \mathrm{eV}$ for $x=1.9$ [9], and 532.7 for $x=2.0$ $[9,10]$. For etched samples, the silicon bound oxygen peaks were at $532.3 \mathrm{eV}\left(\mathrm{Si}^{3+}\right)$ and $532.6 \mathrm{eV}\left(\mathrm{Si}^{4+}\right)$. The oxidation components are given in Table 3. 


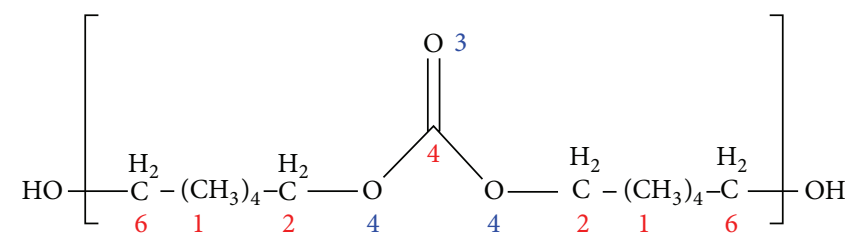

(a)

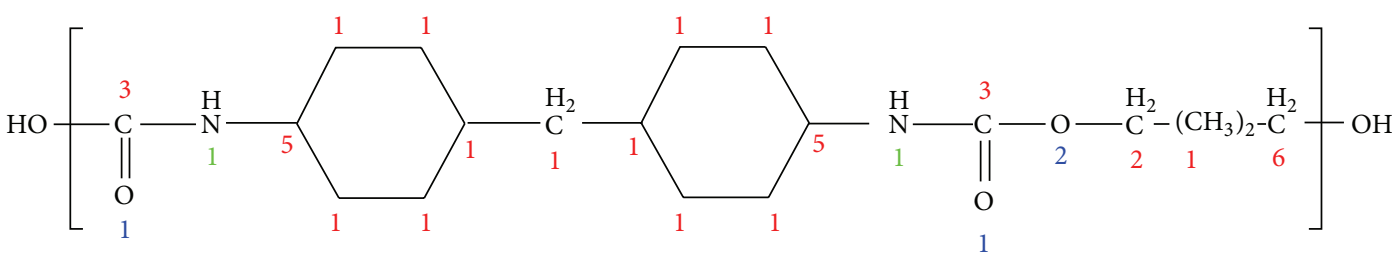

(b)

Figure 2: Model molecular structure of Chronoflex AL: (a) polycarbonate matrix component and (b) aliphatic hard segment composed of HMDI and 1,4 butanediol. The chemical environments of the soft (a) and hard (b) segments: carbon (red), nitrogen (green), and oxygen (blue).

TABLE 2: Chemical groups and environments present in the derived structure of Chronoflex PU. The underscored atom shown in the group column is the contributing chemical environment of that row.

\begin{tabular}{|c|c|c|c|c|c|}
\hline Chemical environment & Instances & Area ratio & Group & $\begin{array}{c}\text { Binding energy } \\
(\mathrm{eV})\end{array}$ & Reference \\
\hline \multicolumn{6}{|l|}{ Carbon } \\
\hline 1 & 21 & $21 / 32$ & $\mathrm{C}-\mathrm{C}$ & 285.0 & {$[6,14]$} \\
\hline 2 & 3 & $3 / 32$ & $\underline{\mathrm{C}}-\mathrm{O}-\mathrm{C}=\mathrm{O}$ & 286.6 & {$[6]$} \\
\hline 3 & 2 & $1 / 16$ & $\mathrm{O}=\mathrm{C}(-\mathrm{O})-\mathrm{N}$ & $287.9-289.4$ & {$[6,15]$} \\
\hline 4 & 1 & $1 / 32$ & $\mathrm{O}=\mathrm{C}(-\mathrm{O})-\mathrm{O}$ & $290.35-290.44$ & {$[6]$} \\
\hline 5 & 2 & $1 / 16$ & $\mathrm{~N}-\mathrm{C}_{\mathrm{hex}}$ & $285.5-286.4$ & {$[6]$} \\
\hline 6 & 3 & $3 / 32$ & C-O-R & $\begin{array}{c}286.1-286.75 \\
286.4-286.8 \\
\end{array}$ & $\begin{array}{l}{[6]} \\
{[14]} \\
\end{array}$ \\
\hline Total & 32 & 1 & & & \\
\hline \multicolumn{6}{|l|}{ Nitrogen } \\
\hline 1 & 1 & 1 & $\mathrm{O}=\mathrm{C}-\mathrm{N}-\mathrm{C}$ & $399.9-400.2$ & {$[6]$} \\
\hline \multicolumn{6}{|l|}{ Oxygen } \\
\hline 1 & 2 & $2 / 7$ & $\mathrm{O}-\mathrm{C}(=\underline{\mathrm{O}})-\mathrm{N}$ & $531.3-532.4$ & [6] \\
\hline 2 & 2 & $2 / 7$ & $\underline{\mathrm{O}}-\mathrm{C}(=\mathrm{O})-\mathrm{N}$ & $\begin{array}{l}533.2-533.9 \\
533.5-533.7\end{array}$ & $\begin{array}{l}{[6]} \\
{[14]}\end{array}$ \\
\hline 3 & 1 & $1 / 7$ & $\mathrm{C}-\mathrm{O}-\mathrm{C}(=\underline{\mathrm{O}})-\mathrm{O}$ & $\begin{array}{l}532.3-532.4 \\
532.0-532.3\end{array}$ & $\begin{array}{l}{[6]} \\
{[14]}\end{array}$ \\
\hline 4 & 2 & $2 / 7$ & $\underline{\mathrm{O}}-\mathrm{C}(=\mathrm{O})-\underline{\mathrm{O}}$ & $\begin{array}{l}533.8-534.0 \\
533.5-533.9\end{array}$ & $\begin{array}{l}{[6]} \\
{[14]}\end{array}$ \\
\hline- & - & - & $\mathrm{C}-\mathrm{O}-\mathrm{H}$ & $\begin{array}{l}532.8-533.1 \\
532.7-533.1\end{array}$ & $\begin{array}{l}{[6]} \\
{[14]} \\
\end{array}$ \\
\hline Total & 7 & 1 & & & \\
\hline
\end{tabular}

The $\mathrm{N} 1 \mathrm{~s}$ peak of the unetched sample consisted of a single component $(399.9 \mathrm{eV})$; the binding energy was similar to isocyanate bonds reported for other polymers [6]. After plasma etching, the $\mathrm{N}$ 1s peak was resolved into 2 distinct components at $399.9 \mathrm{eV}$ and $401.6 \mathrm{eV}$, which contributed 70 at. $\%$ and 30 at.\%, respectively, to the nitrogen peak (Figure 5). The component at $401.6 \mathrm{eV}$ was most likely due to formation of ammonium ions by cross-linking [6]. It was unlikely that oxidation occurred at the nitrogen position, as that would incur a much higher chemical shift (e.g., $\mathrm{NO}_{2}$ is $c a .+5.0 \mathrm{eV}$ from $399.9 \mathrm{eV}$ ) [6].

3.2. Protein Adsorption. Samples that were incubated with culture medium and analysed by XPS had peaks for carbon, 


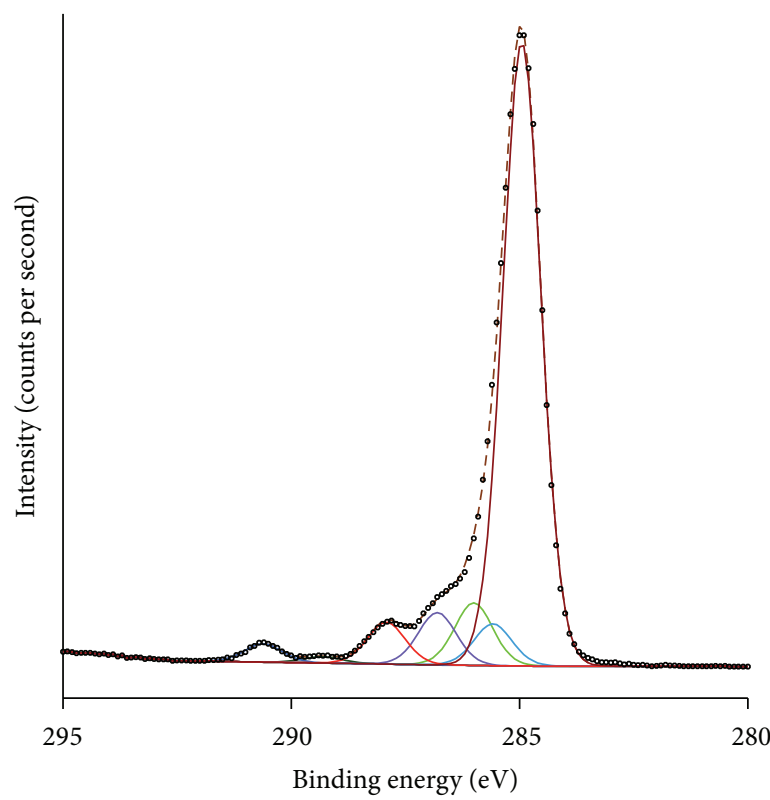

(a)

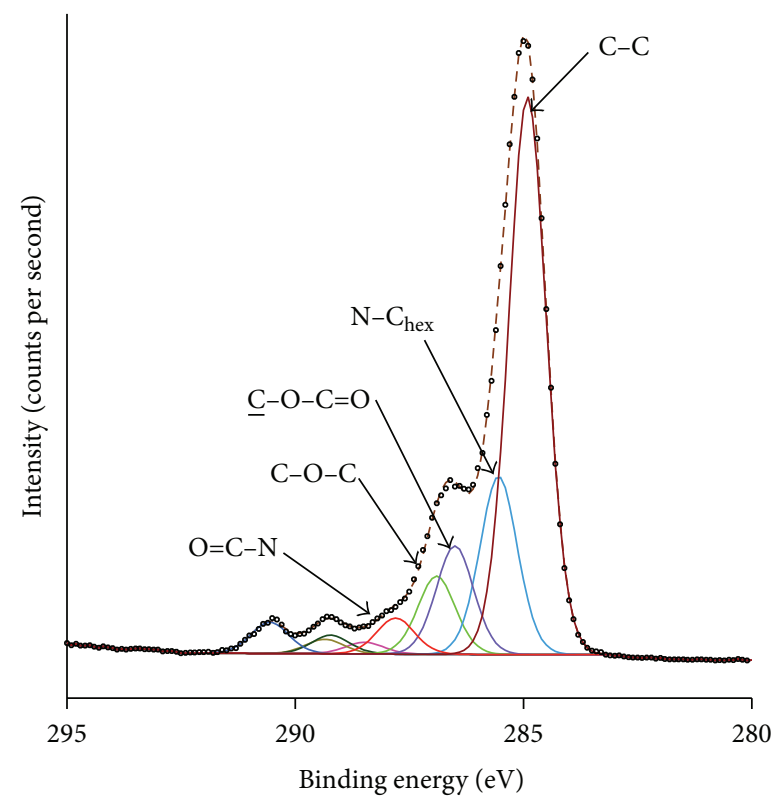

(b)

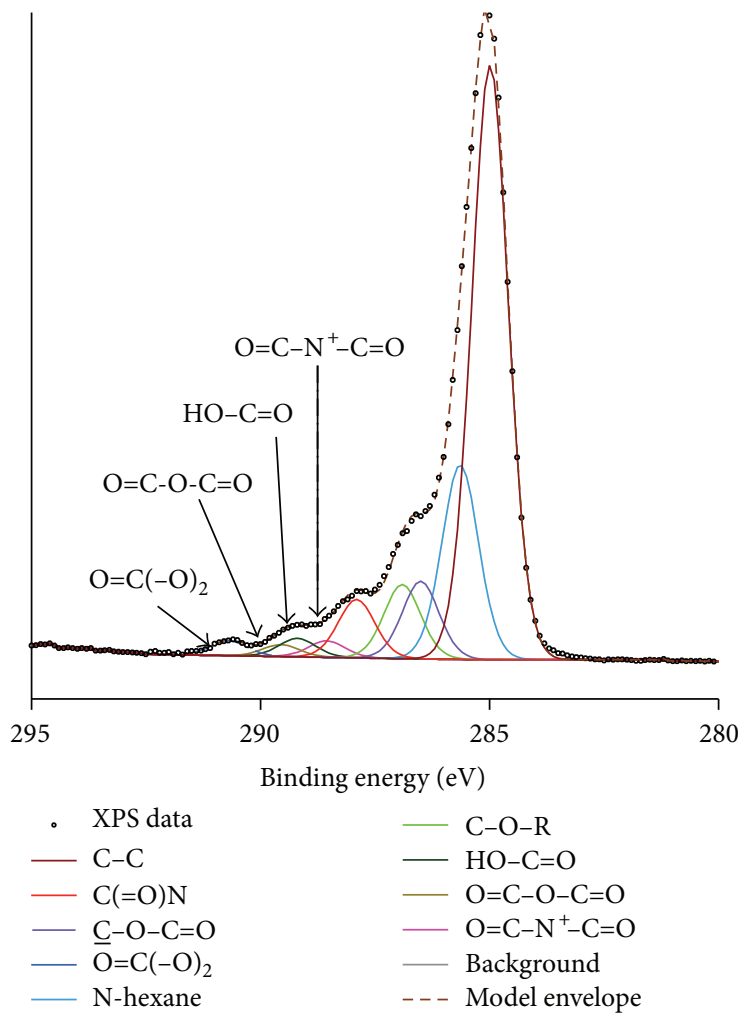

(c)

FIGURE 3: High resolution spectrum for C $1 \mathrm{~s}$ unetched membrane (a) and membranes etched at (b) $20 \mathrm{~W} 40 \mathrm{~s}$ and (c) $20 \mathrm{~W} 80 \mathrm{~s}$.

oxygen, nitrogen, silicon, sulphur, sodium, and chlorine. A control sample was preincubated with sterile DI water; sulphur and buffer salts were undetected (Table 4).

The silicon signal was stronger on unetched PU incubated for 2 days and reduced but still present after 5 days (Figure 6, Table 4 ). The Si $2 p$ peak was as strong as on nonincubated samples and was a singlet with components at $102.2 \mathrm{eV}$ ( $\mathrm{Si}$ II) and $102.8 \mathrm{eV}$ (Si III). In each scanned area, sulphur was detected regardless of whether or not the silicon signal was present (Table 4), as shown in Figure 6.

On the etched PU surface, silicon was not detectable above the background signal following either 2 or 5 days 


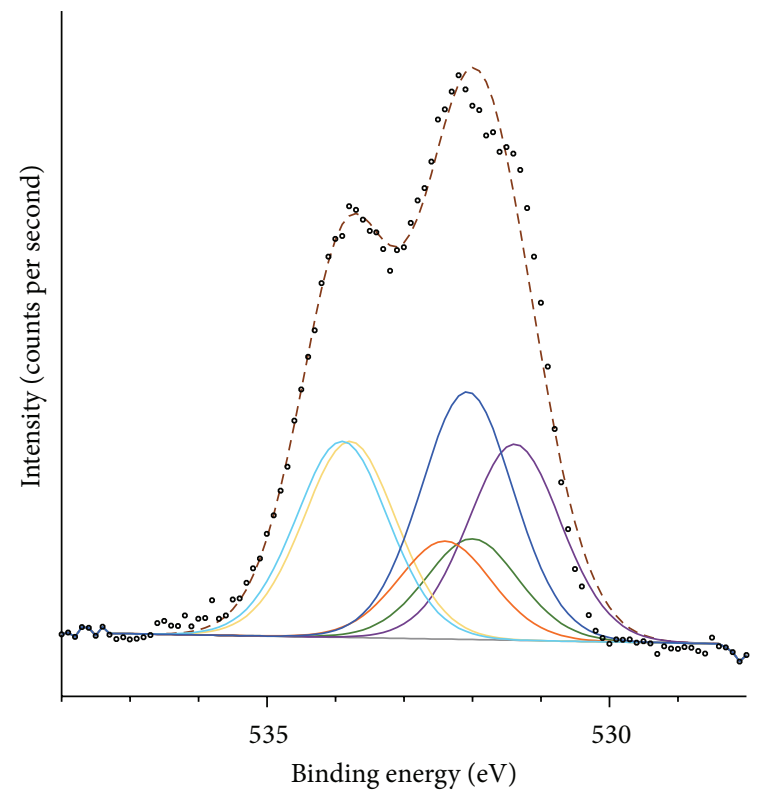

(a)

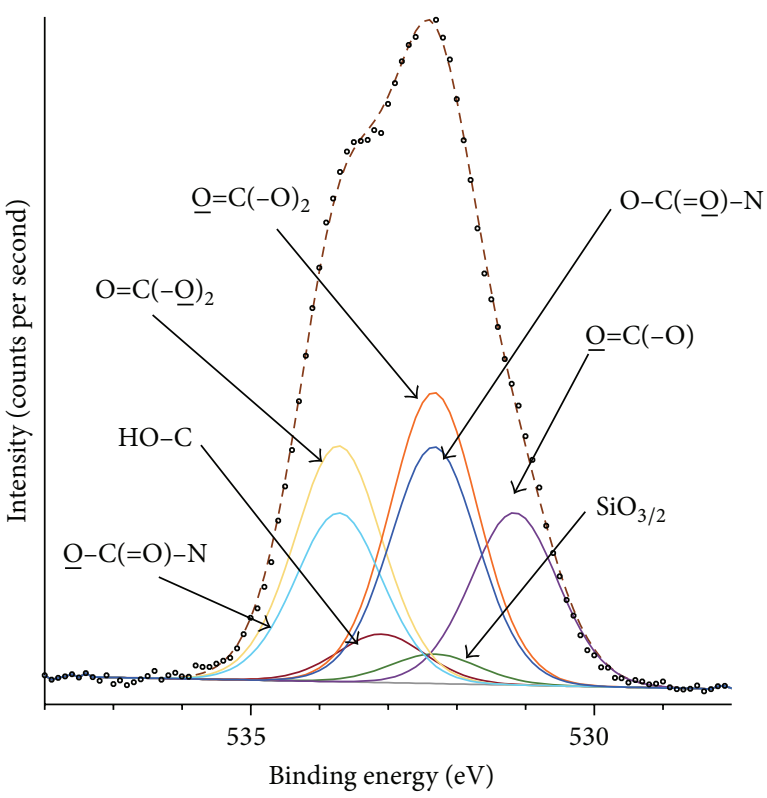

(b)

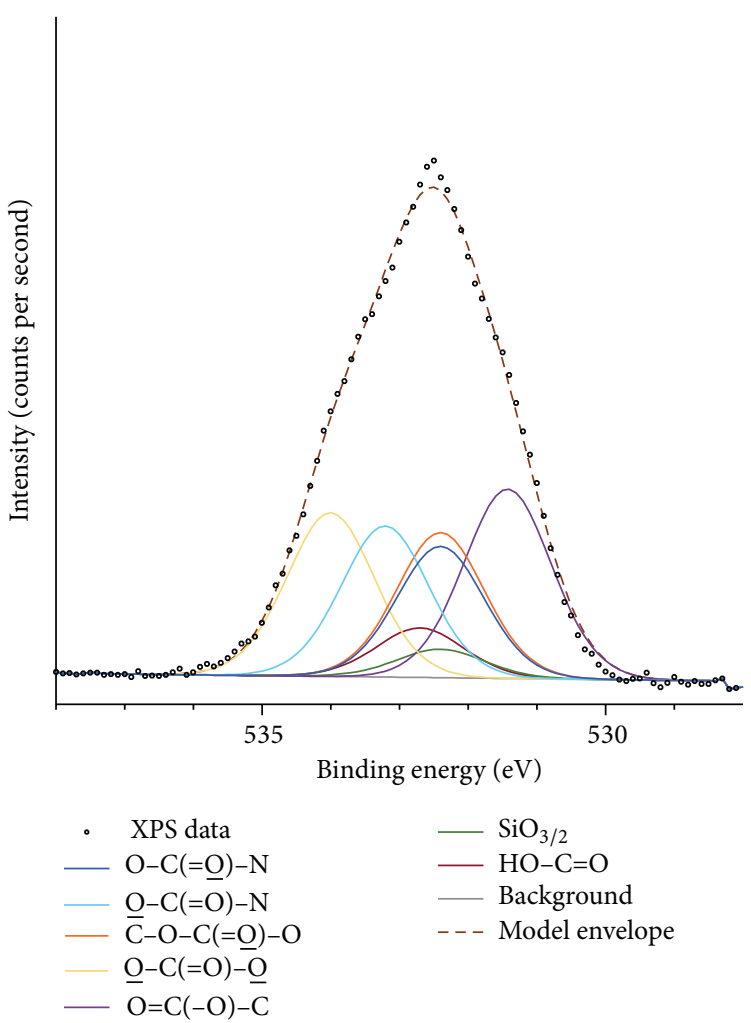

(c)

Figure 4: High resolution XPS spectrum of the O $1 \mathrm{~s}$ peak for PU: (a) unetched and etched at $20 \mathrm{~W}$ for (b) $40 \mathrm{~s}$ and (c) $80 \mathrm{~s}$.

of incubation (Figure 7, Table 4). The Si 2p values shown in Table 4 have high error due to the software automatically trying to analyse peaks that were at background levels.

3.3. Cell Adhesion. Cells were seeded onto unetched and etched PU that was preincubated for $48 \mathrm{~h}$ with culture medium. Phase contrast micrographs of cells on PU are shown in Figure 8. On the unetched PU, cells were mostly of a round morphology, but, on the etched PU, nonrounded morphology was evident $3 \mathrm{~h}$ after seeding. After 1 day, cells on both surfaces had fusiform morphology. A confluent monolayer was formed on the etched PU within 3 days; 


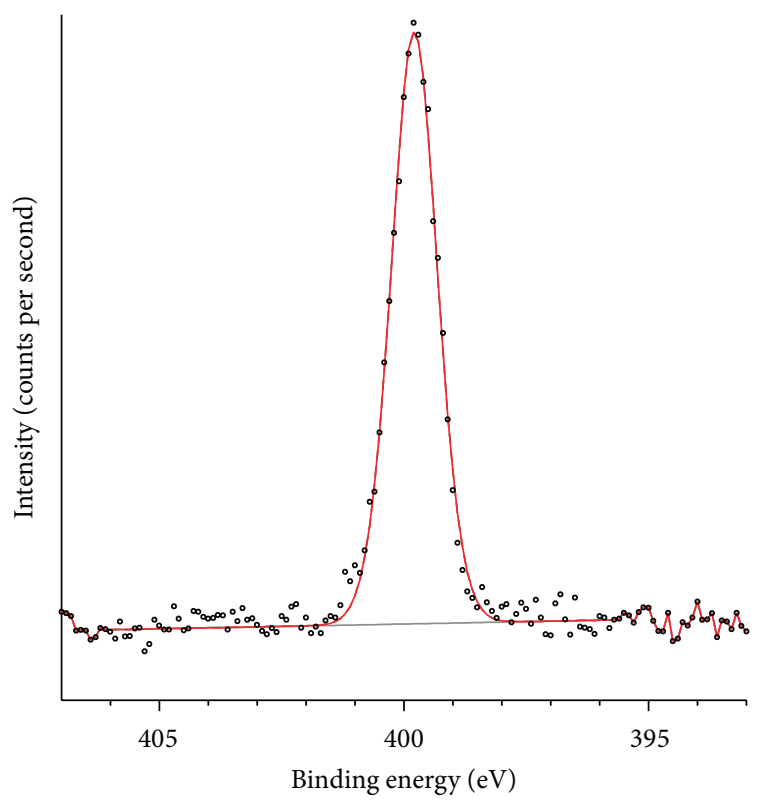

(a)

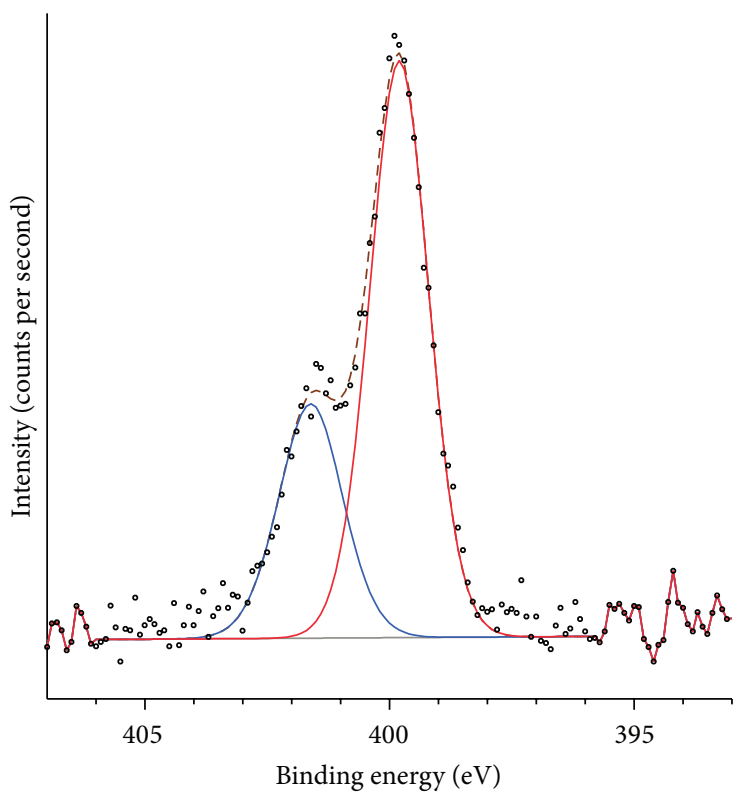

(b)

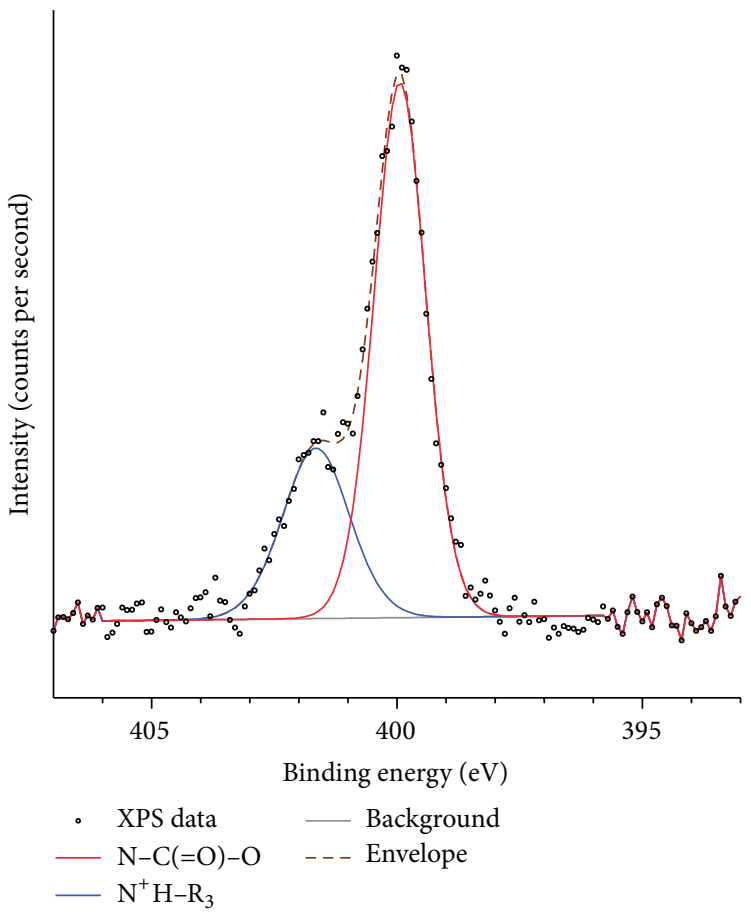

(c)

Figure 5: High resolution XPS spectrum of the N 1s peak for PU membranes: (a) unetched and etched at $20 \mathrm{~W}$ for (b) $40 \mathrm{~s}$ and (c) $80 \mathrm{~s}$.

however on the unetched PU the cells aggregated to form clusters. The clusters continued to grow in size during the 8day culture period.

\section{Discussion}

A model was fitted to the XPS data, based on a theoretical structure. The model can be used as the basis to determine changes to the PU surface following oxidation by plasma etching and so aid selection of a suitable preparation regime for a cell culture substrate. Unetched membranes revealed a relatively high standard deviation of multiple elements, which has also been documented with polyether urethanes [17]. The $\mathrm{C}: \mathrm{O}$ atomic ratio was $6.7 \pm 0.55$, and the $\mathrm{C}: \mathrm{N}$ ratio was $23.1 \pm 2.11$, both of which were higher than the theoretical bulk ratios (5.33 and 16.0, resp.). This may not reflect on the accuracy of the model, as it has been shown that PU copolymers alter their morphology depending 


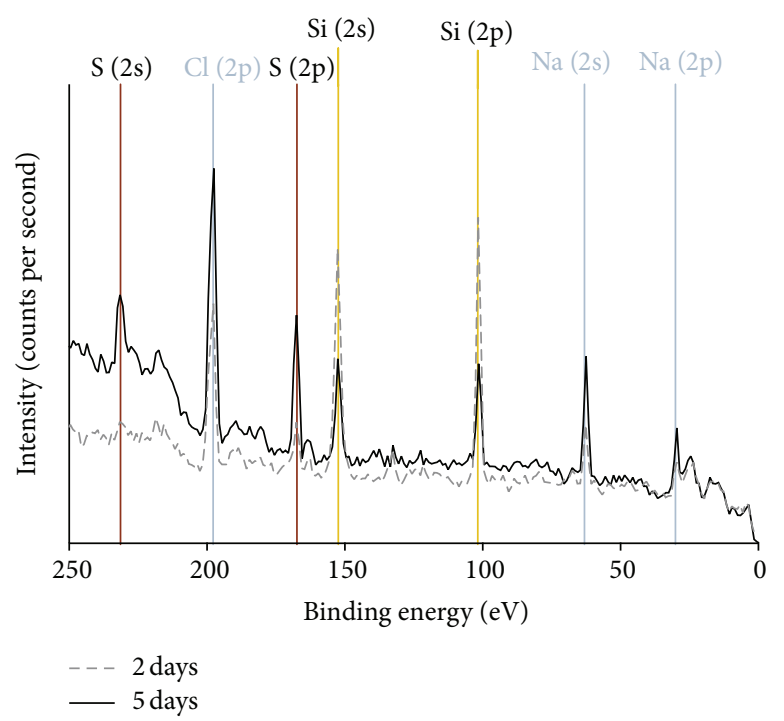

FIGURE 6: XPS spectrum (truncated) of unetched PU incubated for 2 and 5 days with culture medium.

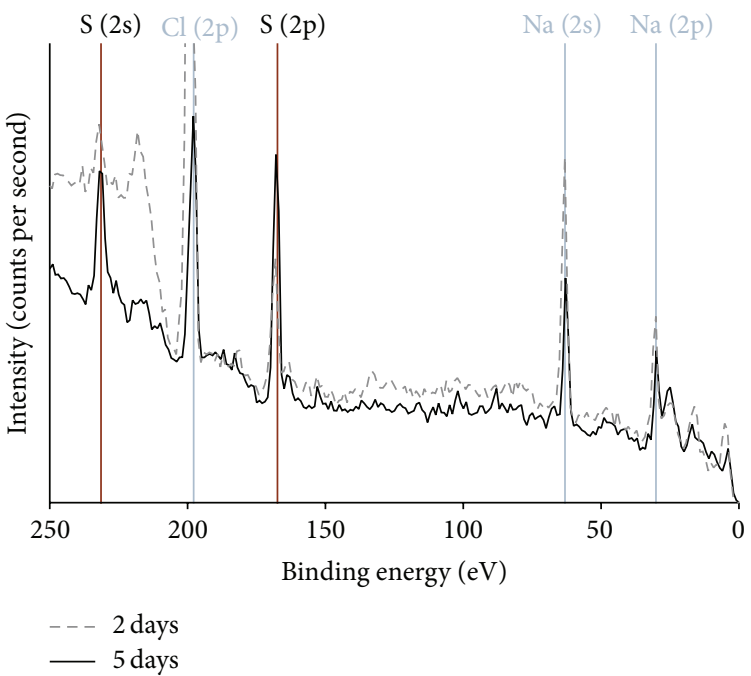

FIGURE 7: XPS spectrum (truncated) of etched (20 W, 40 s) PU incubated for 2 and 5 days with culture medium.

on the environment $[18,19]$. Adventitious carbon, on the unetched samples, may also skew the analysis [20]; unetched samples were stored in aluminium foil and after etching were transferred to the XPS analyser chamber within $3 \mathrm{~h}$; therefore adventitious carbon was unlikely.

Following etching the $\mathrm{C}: \mathrm{O}$ ratio became $3.7 \pm 0.17$ and $4.3 \pm 0.15$ for $20 \mathrm{~W} 40 \mathrm{~s}$ and $80 \mathrm{~s}$, respectively, while the $\mathrm{C}: \mathrm{N}$ ratio was $23.3 \pm 0.95$ and $18.5 \pm 0.75$. The model indicated that etching increased the proportion of $\mathrm{C}=\mathrm{O}$ (C 1 s: 286.5 and $289.3 \mathrm{eV}$; $\mathrm{O} 1 \mathrm{~s}$ : 531.4 and $532.4 \mathrm{eV}$ ), as well as introducing cross-linking involving nitrogen. Peaks corresponding to $\mathrm{HO}-\mathrm{C}=\mathrm{O}$ were found in both $\mathrm{C} 1 \mathrm{~s}$ and $\mathrm{O} 1 \mathrm{~s}$. Hydroxyl groups, in the case of polystyrene, have been proven to be essential for cell adhesion [21].

Incubation of cell culture substrates with proteins, particularly proteins with the RGD sequence, improves cell adhesion. PU was incubated with a protein mixture, and it was determined that etched membranes had complete coverage (Figure 7). Unetched PU showed strong signals for silicon and weaker signals for sulphur, in comparison to etched PU. The presence of both signals suggests that protein adsorption sites were limited on the unetched surface. Membranes were handled at the edge using tweezers, which may have led to variation in the quantity of adsorbed protein disturbed/removed during transfer from the incubation plate to the washing plate; however analysis was carried out on the central region.

Osteosarcoma cells cultured on the unetched PU were unable to reach confluence. Initially the cells remained rounded, probably due to the high surface hydrophobicity [2]. Over time they formed clusters; this indicates that there may be an inhomogeneous spatial distribution of cell adhesion sites on the material. Cells on the etched PU demonstrated the ability to adhere and expand similar as to when seeded 


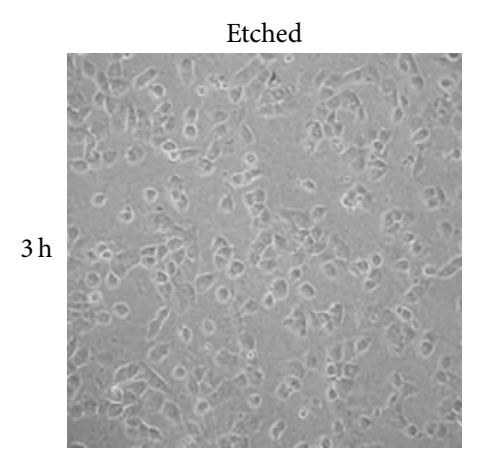

(a)

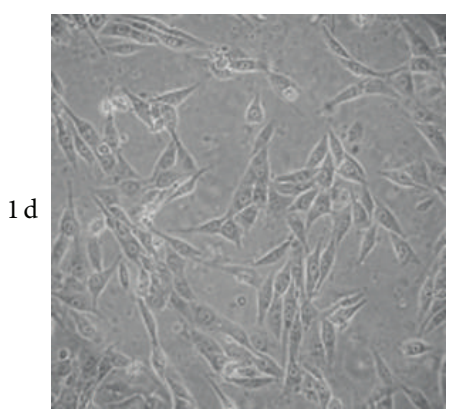

(c)

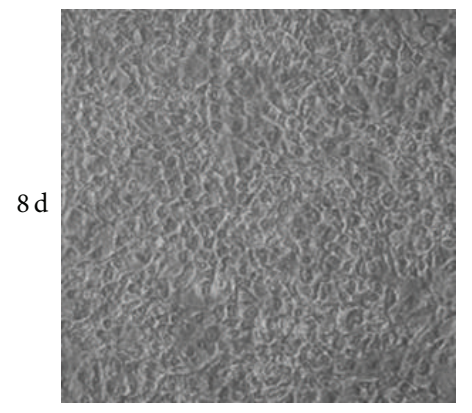

(e)

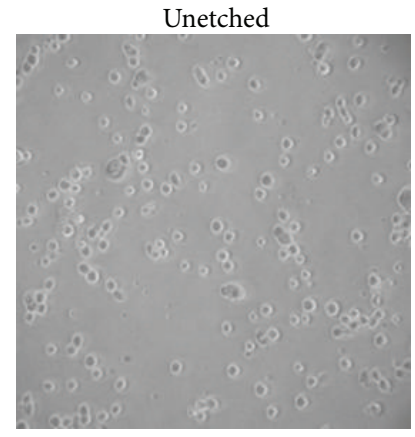

(b)

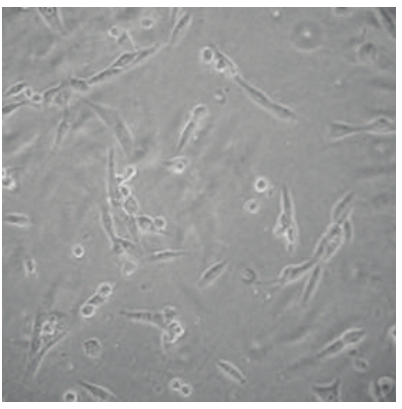

(d)

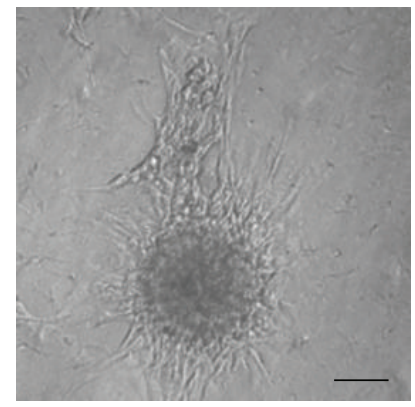

(f)

FIgURE 8: Phase contrast micrographs of MG-63 cells on etched and unetched PU after 2 h, 1 day, and 8 days of static culture. Scale bar is $100 \mu \mathrm{m}$.

TABLE 3: Oxidation model for plasma etched PU, showing the predicted contribution of each group to the total oxidation. Data shows mean $\pm \mathrm{SD}$ for $n=3$.

\begin{tabular}{|c|c|c|c|c|c|c|c|}
\hline \multirow{2}{*}{ Etching parameters } & \multicolumn{7}{|c|}{ Composition (at.\%) } \\
\hline & $\underline{\mathrm{O}}=\mathrm{C}(-\mathrm{O})-\mathrm{N}$ & $\underline{\mathrm{O}}-\mathrm{C}(=\mathrm{O})-\mathrm{N}$ & $\underline{\mathrm{O}}=\mathrm{C}(-\mathrm{O})_{2} \mathrm{R}$ & $(\underline{\mathrm{O}}-)_{2} \mathrm{C}=\mathrm{O}$ & $\mathrm{O}=\mathrm{C}(-\mathrm{O}) \mathrm{R}$ & $\mathrm{HO}-\mathrm{C}=\mathrm{O}$ & $\mathrm{SiO}_{x}$ \\
\hline Unetched & $17.2 \pm 0.4$ & $9.4 \pm 0.1$ & $9.4 \pm 0.1$ & $9.4 \pm 0.1$ & N/A & N/A & $4.7 \pm 0.2$ \\
\hline $20 \mathrm{~W} 40 \mathrm{~s}$ & $10.0 \pm 0.1$ & $7.2 \pm 0.1$ & $12.4 \pm 0.1$ & $10.1 \pm 0.1$ & $7.9 \pm 0.4$ & $0.5 \pm 0.1$ & $1.3 \pm 0.1$ \\
\hline $20 \mathrm{~W} 80 \mathrm{~s}$ & $8.0 \pm 1.2$ & $8.3 \pm 0.9$ & $10.1 \pm 2.1$ & $8.5 \pm 1.4$ & $10.8 \pm 1.2$ & $1.2 \pm 0.6$ & $1.6 \pm 0.3$ \\
\hline $50 \mathrm{~W} 40 \mathrm{~s}$ & $7.9 \pm 1.5$ & $8.6 \pm 0.6$ & $10.6 \pm 1.8$ & $8.2 \pm 0.7$ & $10.6 \pm 0.8$ & $0.9 \pm 0.1$ & $1.9 \pm 0.1$ \\
\hline $50 \mathrm{~W} 80 \mathrm{~s}$ & $10.5 \pm 0.3$ & $6.3 \pm 1.7$ & $12.4 \pm 1.9$ & $8.0 \pm 0.7$ & $9.9 \pm 0.7$ & $0.7 \pm 0.1$ & $1.4 \pm 0.3$ \\
\hline $100 \mathrm{~W} 40 \mathrm{~s}$ & $7.2 \pm 0.1$ & $7.3 \pm 0.5$ & $10.6 \pm 0.1$ & $9.0 \pm 0.7$ & $9.3 \pm 0.3$ & $0.9 \pm 0.0(2)$ & $4.3 \pm 0.1$ \\
\hline $100 \mathrm{~W} 80 \mathrm{~s}$ & $8.3 \pm 0.7$ & $8.4 \pm 1.1$ & $11.1 \pm 1.0$ & $11.6 \pm 0.9$ & $6.5 \pm 0.3$ & $0.7 \pm 0.0(4)$ & $2.7 \pm 0.5$ \\
\hline $180 \mathrm{~W} 40 \mathrm{~s}$ & $9.4 \pm 0.1$ & $8.6 \pm 0.6$ & $11.7 \pm 0.1$ & $11.7 \pm 0.9$ & $4.7 \pm 0.6$ & $0.7 \pm 0.1$ & $2.4 \pm 0.4$ \\
\hline $180 \mathrm{~W} 80 \mathrm{~s}$ & $7.5 \pm 0.4$ & $5.5 \pm 2.1$ & $4.6 \pm 0.5$ & $14.8 \pm 1.3$ & $5.1 \pm 0.2$ & $2.4 \pm 0.1$ & $6.9 \pm 0.1$ \\
\hline
\end{tabular}


TABLE 4: Surface composition of PU membrane incubated with culture medium. Data shows mean with SD $(n=3)$. Cl $2 \mathrm{~s}$ and Na $2 \mathrm{~s}$ were excluded from the calculation of elemental proportions.

\begin{tabular}{|c|c|c|c|c|c|c|c|c|c|c|}
\hline \multirow{3}{*}{ Incubation period (days) and substrate } & \multicolumn{10}{|c|}{ Composition (at.\%) } \\
\hline & \multicolumn{2}{|c|}{$\mathrm{C} 1 \mathrm{~s}$} & \multicolumn{2}{|c|}{$\mathrm{N}$ 1s } & \multicolumn{2}{|c|}{$\mathrm{O} 1 \mathrm{~s}$} & \multicolumn{2}{|c|}{$S 2 p$} & \multicolumn{2}{|c|}{ Si $2 p$} \\
\hline & Mean & SD & Mean & SD & Mean & SD & Mean & SD & Mean & SD \\
\hline $5 \mathrm{~d}$, etched & 63.9 & 1.4 & 11.9 & 0.5 & 22.1 & 0.3 & 2.0 & 0.6 & 0.1 & 0.2 \\
\hline $5 \mathrm{~d}$, unetched & 70.8 & 4.9 & 9.6 & 1.6 & 17.4 & 3.4 & 1.3 & 0.4 & 0.9 & 0.6 \\
\hline $2 \mathrm{~d}$, etched & 65.5 & 2.8 & 11.5 & 0.2 & 21.4 & 2.0 & 1.5 & 0.9 & 0.1 & 0.1 \\
\hline $2 \mathrm{~d}$, unetched & 71.1 & 4.0 & 7.0 & 1.9 & 17.5 & 2.3 & 0.5 & 0.4 & 3.9 & 0.5 \\
\hline $1 \mathrm{~d}$, etched & 63.4 & 0.5 & 12.1 & 0.2 & 22.7 & 0.3 & 1.6 & 0.3 & 0.2 & 0.1 \\
\hline $1 \mathrm{~d}$, unetched & 65.4 & 4.2 & 11.0 & 1.0 & 21.7 & 2.4 & 1.8 & 1.0 & 0.2 & 0.3 \\
\hline Control & 76.9 & 2.8 & 3.1 & 0.3 & 15.8 & 1.9 & Nil & - & 4.3 & 0.64 \\
\hline
\end{tabular}

onto tissue culture polystyrene [2]. XPS of protein incubated etched PU did not show a silicon signal, which indicated complete protein coverage, which may have been a key factor in cells achieving confluence. This suggests that the oxidation, due to etching, was effective at increasing available protein and cell adhesion sites. According to the model, the hydroxyl groups accounted for a very small proportion of oxygen moieties, but the evidence shows that it was sufficient.

\section{Conclusions}

It has been shown that oxidative plasma etching of a medical grade PU alters the surface chemistry and roughness. XPS data showed cross-linking at the isocyanate group, involving 30 at.\% of the nitrogen. Oxidation of the surface added hydroxyl and additional carbonyl groups. The former oxygen moieties were most likely responsible for the improved protein adsorption on etched surfaces and consequently the improved cell adhesion.

\section{Conflict of Interests}

The authors declare that there is no conflict of interests regarding the publication of this paper.

\section{Acknowledgments}

This project was funded through an EPSRC Grant, EP/ P505658/1, for Matthew Moles. Assistance from Mrs. Emily Smith with collecting XPS data and for discussions of the data is gratefully acknowledged. The authors thank the United Kingdom Society for Biomaterials for the opportunity to present this paper at the 2013 conference.

\section{References}

[1] A. J. Engler, M. A. Griffin, S. Sen, C. G. Bönnemann, H. L. Sweeney, and D. E. Discher, "Myotubes differentiate optimally on substrates with tissue-like stiffness: pathological implications for soft or stiff microenvironments," The Journal of Cell Biology, vol. 166, no. 6, pp. 877-887, 2004.

[2] D. M. Moles, C. A. Scotchford, and A. C. Ritchie, "Development of an elastic cell culture substrate for a novel uniaxial tensile strain bioreactor," Journal of Biomedical Materials Research A, 2013.

[3] Q. Chen, S. Liang, and G. A. Thouas, "Elastomeric biomaterials for tissue engineering," Progress in Polymer Science, vol. 38, no. 3-4, pp. 584-671, 2013.

[4] C. Moraes, Y. K. Kagoma, B. M. Beca, R. L. M. Tonelli-Zasarsky, Y. Sun, and C. A. Simmons, "Integrating polyurethane culture substrates into poly(dimethylsiloxane) microdevices," Biomaterials, vol. 30, no. 28, pp. 5241-5250, 2009.

[5] H. J. Mathieu, "Auger electron spectroscopy," in Surface Analysis the Principal Techniques, J. Vickerman and I. Gilmore, Eds., pp. 9-46, John Wiley \& Sons, West Sussex, UK, 2009.

[6] G. Beamson and D. Briggs, High Resolution XPS of Organic Polymers: The Scienta ESCA300 Database, Wiley, Chichester, UK, 1992.

[7] H. Kim, M. Seo, M.-H. Park, and J. Cho, "A critical size of silicon nano-anodes for lithium rechargeable batteries," Angewandte Chemie International Edition, vol. 49, no. 12, pp. 2146-2149, 2010.

[8] L.-A. O'Hare, B. Parbhoo, and S. R. Leadley, "Development of a methodology for XPS curve-fitting of the Si $2 p$ core level of siloxane materials," Surface and Interface Analysis, vol. 36, no. 10, pp. 1427-1434, 2004.

[9] S. S. Chao, Y. Takagi, G. Lucovsky et al., "Chemical states study of $\mathrm{Si}$ in $\mathrm{SiO}_{x}$ films grown by PECVD," Applied Surface Science, vol. 26, no. 4, pp. 575-583, 1986.

[10] J. R. Pitts, T. M. Thomas, A. W. Czanderna, and M. Passler, "XPS and ISS of submonolayer coverage of $\mathrm{Ag}$ on $\mathrm{SiO}_{2}$," Applied Surface Science, vol. 26, no. 1, pp. 107-120, 1986.

[11] F. Rochet, G. Dufour, H. Roulet et al., "Modification of SiO through room-temperature plasma treatments, rapid thermal annealings, and laser irradiation in a nonoxidizing atmosphere," Physical Review B, vol. 37, no. 11, pp. 6468-6477, 1988.

[12] B. H. Augustine, W. C. Hughes, K. J. Zimmermann, A. J. Figueiredo, X. Guo, and C. C. Chusuei, "Surface characterization of oxygen-plasma treated poss-based acrylic polymer thin films," Polymer Preprints, vol. 48, no. 1, pp. 789-788, 2007.

[13] M. Szycher and A. M. Reed, inventors, PolyMedia Industries, assignee. Biostable polyurethane products, 1993.

[14] G. P. López, D. G. Castner, and B. D. Ratner, "XPS O 1s binding energies for polymers containing hydroxyl, ether, ketone and ester groups," Surface and Interface Analysis, vol. 17, no. 5, pp. 267-272, 1991.

[15] M. J. Hearn, B. D. Ratner, and D. Briggs, "SIMS and XPS studies of polyurethane surfaces. 1. Preliminary studies," Macromolecules, vol. 21, no. 10, pp. 2950-2959, 1988. 
[16] J. C. Bolger, "Acid base interactions between oxide surfaces and polar organic compounds," in Adhesion Aspects of Polymeric Coatings, K. L. Mittal, Ed., pp. 3-18, Plenum Press, New York, NY, USA, 1983.

[17] B. J. Tyler, B. D. Ratner, D. G. Castner, and D. Briggs, "Variations between Biomer lots. I. Significant differences in the surface chemistry of two lots of a commercial poly(ether urethane)," Journal of Biomedical Materials Research, vol. 26, no. 3, pp. 273289, 1992.

[18] H.-B. Lin, K. B. Lewis, D. Leach-Scampavia, B. D. Ratner, and S. L. Cooper, "Surface properties of RGD-peptide grafted polyurethane block copolymers: variable take-off angle and coldstage ESCA studies," Journal of Biomaterials Science, vol. 4, no. 3, pp. 183-198, 1993.

[19] D. Zhang, R. S. Ward, Y. R. Shen, and G. A. Somorjai, "Environment-induced surface structural changes of a polymer: an in situ IR + visible sum-frequency spectroscopic study," The Journal of Physical Chemistry B, vol. 101, no. 44, pp. 9060-9064, 1997.

[20] S. Evans, "Correction for the effects of adventitious carbon overlayers in quantitative XPS analysis," Surface and Interface Analysis, vol. 25, no. 12, pp. 924-930, 1997.

[21] A. S. Curtis, J. V. Forrester, C. McInnes, and F. Lawrie, "Adhesion of cells to polystyrene surfaces," Journal of Cell Biology, vol. 97, no. 5, part 1, pp. 1500-1506, 1983. 

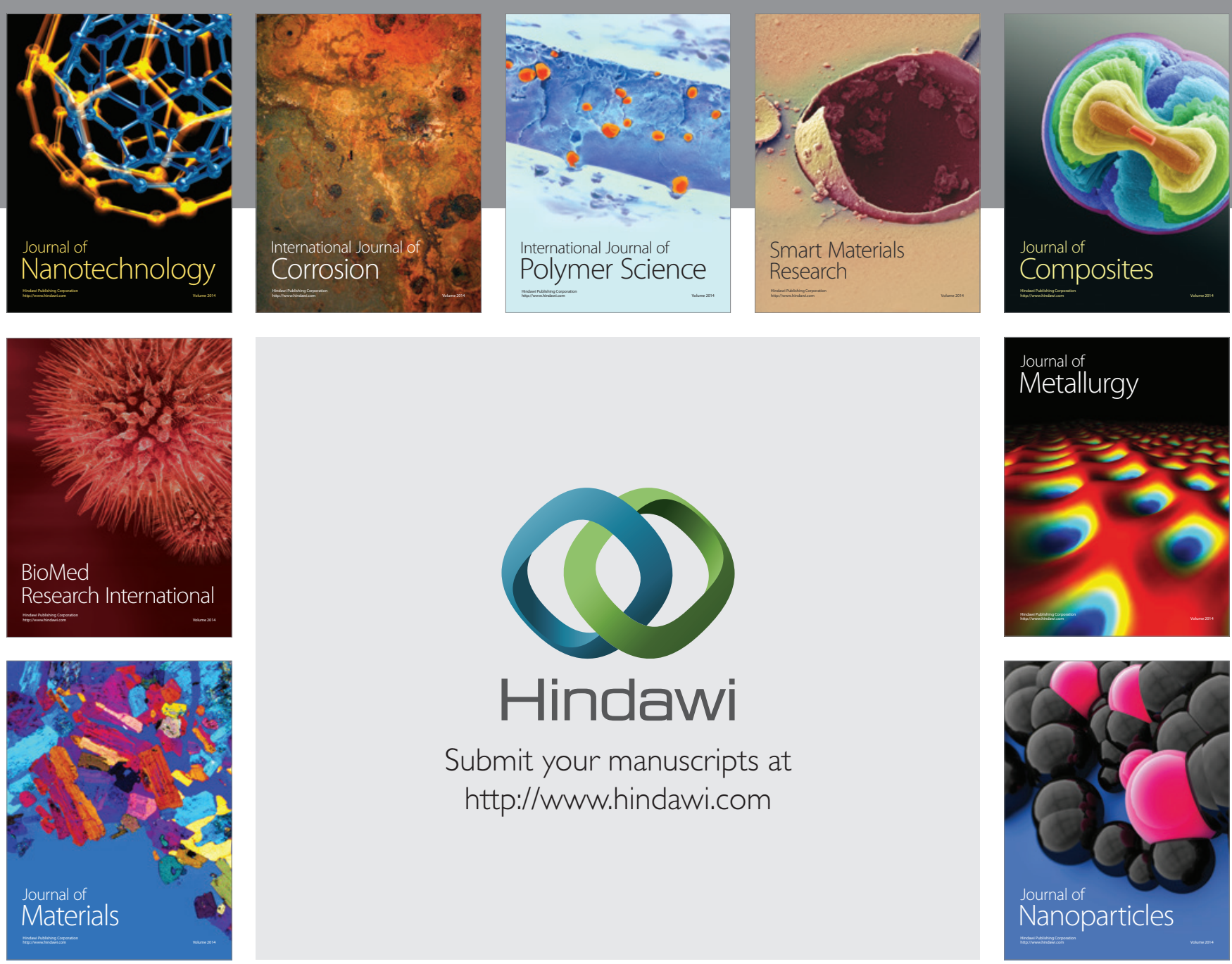

Submit your manuscripts at http://www.hindawi.com
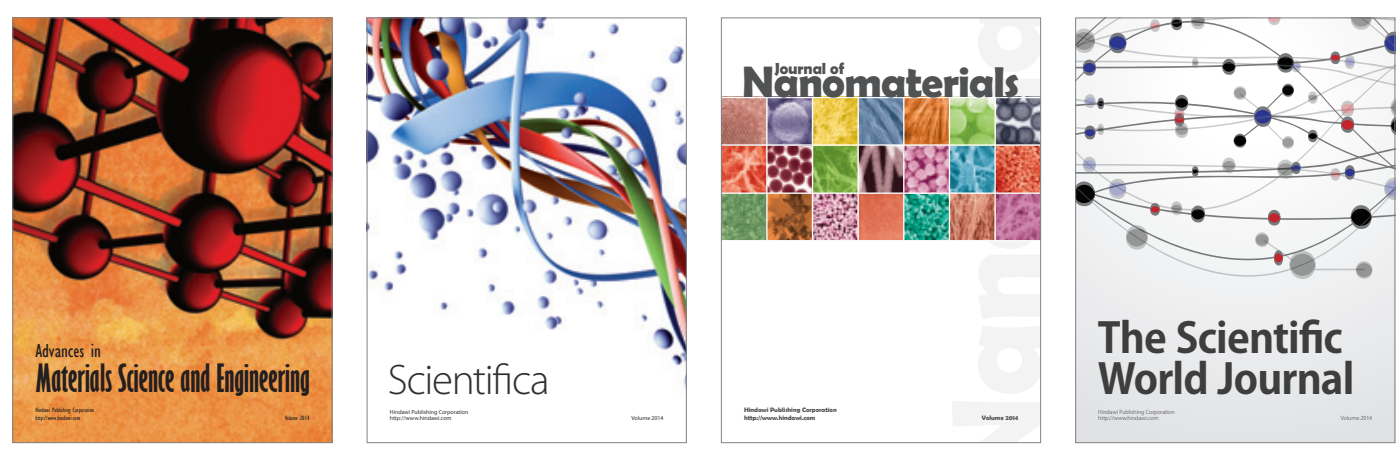

\section{The Scientific World Journal}
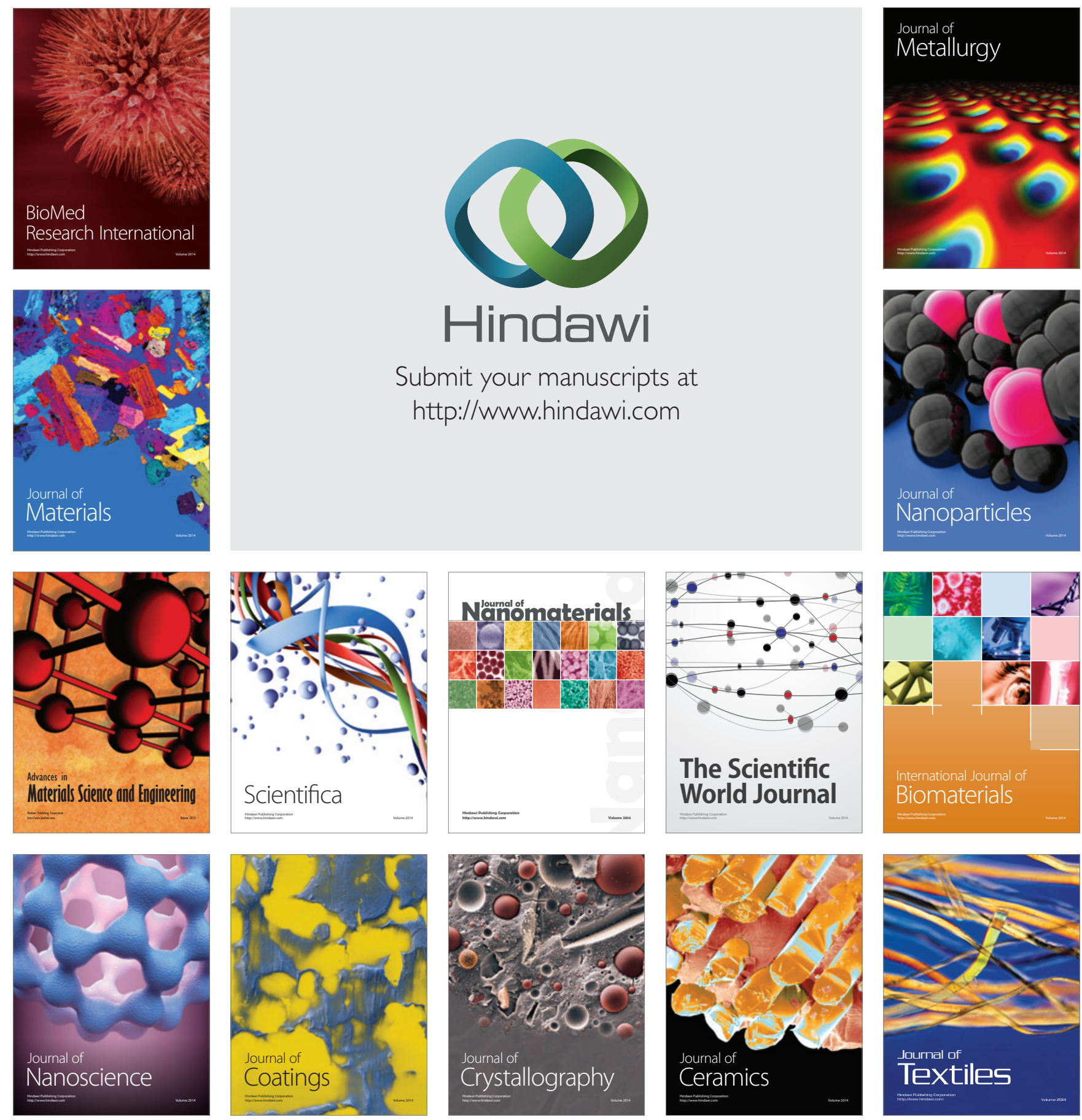